\title{
GENE TRANSFER ON Betta imbellis THROUGH TRANSFECTION METHOD WITH DIFFERENT DNA CONCENTRATION
}

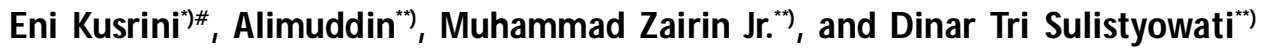 \\ *A Aquaculture Post-graduate program, Department of Aquaculture, FPIK, Bogor Agricultural University \\ Research and Development Institute for Ornamental Fish Culture \\ * Department of Aquaculture, Marine and Fishery Faculty, Bogor Agricultural University
}

\begin{abstract}
Big size betta (giant) have a high economic value compared to normal size betta, and over expression of growth hormone gene can produce a giant fish. As an initial step of giant transgenic betta production, this study was conducted to obtain DNA plasmid concentration which provides higher hatching and survival rates of betta larvae. This study used pCcBA-PhGH gene construct that containing growth hormone gene of Siamese catfish (PhGH) and it is controlled by the common carp $\beta$-actin (CCBA) promoter. Betta imbellis broodstocks were spawned naturally, and embryos were collected 1-2 minutes after spawning time. One hundred embryos were dipped in $2 \mathrm{~mL}$ of transfectan X-treme gene which contained the CcBA-PhGH expression vector $(50 \mu \mathrm{g} / \mathrm{mL})$, on room temperature for about 30 minutes. Treatments on this study were different transfectant : DNA plasmid ratios, namely: A $(0.75 \mu \mathrm{L}: 0.25 \mu \mathrm{L}) ; \mathrm{B}(0.75 \mu \mathrm{L}: 0.50 \mu \mathrm{L}) ; \mathrm{C}(0.75 \mu \mathrm{L}$ : $0.75 \mu \mathrm{L}$ ), D as control 1 (without transfectant, $0.25 \mu \mathrm{L} \mathrm{DNA})$; E as control $2(0.75 \mu \mathrm{L}$ transfectant, without DNA), and $F$ as control 3 (without transfectant and without DNA). Each treatment was repeated three times. Transfection embryos were hatched on a container ( $1 \mathrm{~L}$ volume). The results showed that hatching rate (HR) and larval survival rate (SR) (at 4 days after hatching) on treatment A were the same as the control, but slightly higher than B and C treatments. PCR analysis with DNA template showing that PhGH gene were found on embryos and larvae (pooled sample) of treatment A, B, and C. Furthermore, RT-PCR analysis showed the existence of PhGH mRNA expression on the pooled samples of embryos and larvae. Therefore, embryo transfection with the mixture of $0.75 \mu \mathrm{L}$ transfectant and $0.25 \mu \mathrm{L}$ gene expression vector can be used to generate betta transgenic.
\end{abstract}

\section{KEYWORDS: gene transfer; growth hormone; B. imbellis; DNA concentration; transfection}

\section{INTRODUCTION}

Giant-sized Betta sp. still becomes favorite fish on international contest, and it is so hard to obtain those fish size (IBC, 2013). The giant-sized betta has a high market value, ranged from IDR 900,000 to IDR 950,000 per fish (IBC, 2013). Betta's breeders in Indonesia have already made some efforts to produce giant betta through selective breeding, but the body size of offspring are not as big as its parents and the number of progenies are less than 10\% per spawning cycle (Personal communication, INBS betta association, 2015). One alternative method which can be applied to produce giant betta is transgenic method. In fact, over

\footnotetext{
\# Correspondence: Aquaculture Post-graduate program, Department of Aquaculture, FPIK, IPB. Jl. Lingkar Akademik, Kampus IPB Dramaga, Bogor 16680, Indonesia.

Phone: + (0251) 8621210

E-mail: ennyperikanan@yahoo.com
}

expression of growth hormone (GH) gene results a giant fish size (Nam et al., 2001; Devlin et al., 2004).

Gene transfer can be carried out through microinjection method (Gusrina et al., 2009), sperm electroporation (Tsai, 2000; Dewi, 2010), vector retroviral utilization or retroviral infection (Gaiano et al., 1996), ballistic bombardment (Kavumpurath et al., 1993), and transfection (Parenrengi et al., 2011; Dunham, 2004). Success story from those gene transfer methods are tested on some fish species (including siamese catfish, golden carp, and catfish), tiger prawn, and some ornamental fishes particularly zebrafish (Danio rerio) and Japanese medaka (Oryzias latipes).

Microinjection method is commonly utilized to produce transgenic fish. However, microinjection method is difficult to apply to small eggs size such as the egg of betta. An alternative method for the small 
egg size is tranfection. Transfection method has been successfully carried out for gene transfer in white shrimp (Sun et al., 2005) and tiger shrimp (Parenrengi et al., 2011).

Betta imbellis is one of the Indonesian native species and have been successfully domesticated in Indonesia (Kusrini et al., 2012). B. imbellis egg size is relatively small $(1.09 \pm 0.04 \mathrm{~mm})$ with thin chorion and spawn naturally. With such eggs characters, transfection method is potential to be applied in order to create transgenic betta fish. The trial of gene transfer in betta fish using transfection method have been tried using GFP gene reporter, but survival rate, and the number of transgenic larvae obtained are limited (Prasetio et al., 2012). Increase transfection efficiency can be obtained by using proper ratio of transfectant and DNA expression vector (Parenrengi et al., 2011; Sun et al., 2005). Thus, this study was conducted to find proper ratio of transfectant and DNA expression vector to increase survival and amount of betta transgenic production.

The $\beta$-actin promoter is a constitutive and ubiquitous promoter (Volckaert et al., 1994). Activity of this promoter in regulating transgene expression has been demonstrated in rainbow trout (Yoshizaki, 2001; Boonanuntanasarn et al., 2002), mud loach fish (Nam et al., 2001), zebrafish (Alimuddin et al., 2003), tilapia (Kobayashi et al., 2007), and siamese pangasius catfish (Dewi et al., 2012). Growth of GH transgenic fish which is controlled by $\beta$-actin promoter is also increased significantly (Nam et al., 2001; Kobayashi et al., 2007). In addition, the growth of GH siamese catfish (PhGH) transgenic with common carp $\beta$-actin (CCBA) promoter is increased by $85 \%$ compared to non-transgenic fish (Dewi et al., 2012). In this study, the pCcBA-PhGH expression vector was used to generate $B$. imbellis transgenic. This study was conducted in order to obtain DNA plasmid concentration which provides higher hatching and survival rates of betta larvae.

\section{MATERIALS AND METHODS}

\section{Egg Collections}

Betta imbellis have been domesticated in Research and Development Institute for Ornamental Fish Culture (BPPBIH), Depok. Those fish are originally obtained from Sumatra Island. Broodstocks were reared in aquarium $\left(15 \mathrm{~cm} \times 20 \mathrm{~cm} \times 20 \mathrm{~cm}^{3}\right)$ at density of one individual were characterized by the presence of foam in the water for male broodstock, while for the mature female was characterized by redness and bulging in the abdomen.
Broodstocks were spawned naturally in pairs (one female and one male). Eggs were collected immediately after spawning by using pipette and spatula. The eggs were collected in a petri dish (diameter 2.5 inches) containing $2 \mathrm{~mL}$ of water.

\section{Gene Construct Preparation}

This study used the pCcBA-PhGH gene expression vector that consisted of siamese catfish (Pangasianodon hypophthalmus) growth hormone cDNA (PhGH) and controlled by common carp $\beta$-actin promoter/CcBA (Dewi et al., 2012). Escherichia coli bacteria carrying $\mathrm{pCcBA}-\mathrm{PhGH}$ plasmid was cultured in Luria Bertani (LB) media (10 g/L polypeptone; $5 \mathrm{~g} / \mathrm{L}$ yeast extract; $10 \mathrm{~g} \mathrm{~L} \mathrm{NaCl}$; pH 7.5) containing kanamycin $100 \mathrm{mg} / \mathrm{L}$ at a shaker with $250 \mathrm{rpm}$ speed, at temperature $37^{\circ} \mathrm{C}$ overnight.

Plasmids were isolated using a DNA plasmid isolation kit (Vivantis) by following the manufacturer instruction. Plasmid concentration was measured using UV-VIS spectrophotometer. DNA was dissolved with $\mathrm{NaCl} 0.95 \%$ to get a final concentration of 50 $\mathrm{mg} / \mathrm{mL}$, and kept in a freezer until used in the next process.

\section{Embryo Transfection}

Introductions of pCcBA-PhGH expression vectors into $B$. imbellis embryo were done via transfection using X-treme Gene (Roche, German) which referred to Prasetio et al. (2013). Approximately 1-2 minutes after spawning, 200 eggs were collected and placed into 2 inches petri dish. After that, each petri dish was added with transfectant and DNA plasmid according to the treatments.

Treatments on this study were different DNA and transfectant ratio, namely: A $(0.75 \mu \mathrm{L}$ transfectant : $0.25 \mu \mathrm{L}$ DNA plasmid); B (0.75 $\mu \mathrm{L}$ transfectant : 0.50 $\mu \mathrm{L}$ DNA plasmid); C (0.75 $\mu \mathrm{L}$ transfectant : $0.75 \mu \mathrm{L}$ DNA plasmid); D DNA control (without transfectant: $0.25 \mu \mathrm{L}$ DNA plasmid); $\mathrm{E}$ transfectant control (0.75 $\mathrm{mL}$ transfectant without DNA plasmid); and $\mathrm{F}$ negative control (without plasmid and without transfection solution). DNA plasmid and transfectant were mixed with $\mathrm{NaCl}$ solution $0.95 \%$ up to $100 \mu \mathrm{L}$. The solution was put into a petri dish containing $B$. imbellis embryos. Transfection was conducted at room temperature for 30 minutes, then embryos were transferred into hatching container. Embryo incubation was done at room temperature $\left(28^{\circ} \mathrm{C}-29^{\circ} \mathrm{C}\right)$.

\section{DNA Extraction and PCR Analysis}

Samples were taken as many as 50 embryos from each treatment at $18,36,54$, and 72 hours after trans- 
fection, and 30 newly hatched larvae (54 and 72 hours) for detecting PhGH gene by PCR method. Eggs and/ or larvae were put into microtube, precipitated by centrifugation, and water discarded using a micropipette. Eggs and larvae were washed with $\mathrm{NaCl}$ solution $(0.009 \mathrm{mg} / \mathrm{L})$, centrifuged, and $\mathrm{NaCl}$ solution was discarded using a micropipette. Subsequently, DNA was extracted using GeneJET Genomic DNA Purification Kit according (Thermo Scientific ${ }^{\circledR}$ ) to the instructions in the manual procedure. PCR amplification was performed using maxima hot start green PCR master mix $2 x$ (Thermo Science). The composition of the PCR reaction was $12.5 \mu \mathrm{L}$ master mix, $1 \mu \mathrm{L} \mathrm{PhGH}$ primer with a concentration of $20 \mathrm{pmol}$ (F3 PhGH: 5'TCT TTA GTC AAG CGA CAT GCG TCG AGA-3 ', and R3 PhGH: 5'-CGC CGA CGA TAA GCA TGC TCA TTT CCA-3 '; (Dewi., 2010), $2 \mu \mathrm{L}$ DNA, and nuclease free water until the total volume up to $25 \mu \mathrm{L}$. PCR amplification program was: $94^{\circ} \mathrm{C}$ pre-denaturation for 5 minutes; $94^{\circ} \mathrm{C}$ denaturation for 30 seconds, $58^{\circ} \mathrm{C}$ annealing for 30 seconds and $72^{\circ} \mathrm{C}$ extension for 30 seconds for 35 cycles; and final extension of $72^{\circ} \mathrm{C}$ for three minutes.

$\beta$-actin gene was used as an internal control DNA loading. Primers used were $F$ primer: 5'-GAA TAT TAT GCT CTG CCC GGT -3 ', and $\beta$-actin primer R: 5 '-CAT ACC CAG AGA GAA TGG CTG-3' (Alimuddin, unpublished). PCR amplification was performed with the program: $94^{\circ} \mathrm{C}$ predenaturation for three minutes; $94^{\circ} \mathrm{C}$ denaturation for 30 seconds, $62^{\circ} \mathrm{C}$ annealing for 30 seconds and $72^{\circ} \mathrm{C}$ extension for 30 seconds for 35 cycles; and a final extension of $72^{\circ} \mathrm{C}$ for three minutes. PCR amplification products were separated by electrophoresis using $1 \%$ agarose gel. Documentation was performed using UV gel doc transilluminator. Amplification target for PhGH gene was 334 bp, and $\beta$-actin was $300 \mathrm{bp}$.

\section{Total RNA Extraction and RT-PCR Analysis}

Retrieval time of embryos and larvae samples number for total RNA extraction was conducted the same as DNA extraction. Isolation of total RNA was performed using Tri-Reagent (Molecular Research Center, Inc., America). A total of 10 ug of total RNA was taken, and cDNA synthesis was performed using Transcriptor First Strand cDNA Synthesis Kit (Roche) with the appropriate procedures in the manual instruction.

Exogenous PhGH expression was analyzed using RT-PCR method. Primer and PCR amplification program for RT-PCR analysis was the same as the analysis of exogenous DNA PhGH. $\beta$-actin gene expression was used as an internal control RNA loading when CDNA synthesis was conducted. RT-PCR products were separated using electrophoresis on $1 \%$ agarose gel, and documented with Gel Documentation System (Biorad).

\section{Test Parameter and Data Analysis}

The differences between treatments were evaluated based on hatching eggs, larvae survival rate and the presence of exogenous PhGH. Hatching eggs were calculated based on number of eggs that hatch into larvae in comparison to amount of eggs that were incubated. Hatching eggs accounted for about 72 hours after spawning. Larval survival rate was calculated on fourth day after hatching (larvae have eaten live feed) and moved from incubation container to larval rearing container. Data were analyzed using analysis of variance at $95 \%$ confidence level with SPSS. PCR and RT-PCR analysis results were evaluated descriptively.

\section{RESULTS AND DISCUSSION}

\section{Hatching and Larvae Survival Rate}

Hatching rate (HR) of $B$. imbellis ranged from $39.0 \%$ to $76.2 \%$ (Table 1). HR of treatment A (DNA plasmid concentration was $0.25 \mu \mathrm{L})$ was higher $(\mathrm{P}<0.05)$ than $\mathrm{B}(0.50 \mu \mathrm{L}$ DNA plasmid concentration) and C (DNA plasmid concentration of $0.75 \mu \mathrm{L}$ ). Meanwhile, the $\mathrm{HR}$ value on treatment $A$ was the same as control (P> 0.05).

Larvae survival rate (SR) aged four days at transfection with DNA plasmid concentration $0.25 \mu \mathrm{L}$ to $0.75 \mu \mathrm{L}$ treatment were same, ranging from $60 \%$ to $80 \%(P>0.05)$, while larval SR of DNA control was $90 \%$ transfectant control was $95 \%$ and negative control was $75 \%$ (Table 1). Control SR also did not different significantly with transfection treatment.

\section{DNA Detection and PhGH Gene Expression}

PCR analysis on transfected embryos and larvae using PhGH primers indicated the presence of DNA band at size approximately $334 \mathrm{bp}$, while on non-transfection controls it was undetected (Figure 1A). Meanwhile, PCR analysis using $\beta$-actin primer showing a 300 bp DNA bands on embryo (the photograph is not shown), transfection larvae and non-transgenic control (Figure 1B).

PhGH mRNA expression analysis was the same with DNA analysis, which DNA band sized 334 bp was obtained in transfection treatment, and there was no DNA band in non-transfection control (Figure 2). Furthermore, DNA band sized $300 \mathrm{bp}$ as a PCR product with $\beta$-actin primers was found in transfection and non-transfection embryos and larvae (Figure 2). 
Table 1. Hatching and survival rate of B. imbellis larvae transfected with different concentration of DNA expression vector

\begin{tabular}{lcc}
\hline \multicolumn{1}{c}{ Transfectan treatment : DNA plasmid Concentration } & Hatching rate (\%) & Survival rate (\%) \\
\hline $\mathrm{A}=0.75 \mu \mathrm{L}: 0.25 \mu \mathrm{L}$ & $63.0 \pm 2.0^{\mathrm{b}}$ & $80 \pm 2.0$ \\
$\mathrm{~B}=0.75 \mu \mathrm{L}: 0.50 \mu \mathrm{L}$ & $39.0 \pm 6.5^{\mathrm{a}}$ & $60 \pm 6.2$ \\
$\mathrm{C}=0.75 \mu \mathrm{L}: 0.75 \mu \mathrm{L}$ & $39.2 \pm 1.4^{\mathrm{a}}$ & $60 \pm 6.2$ \\
$\mathrm{D}=$ DNA Control (without transfectant : $0.25 \mu \mathrm{L}$ DNA plasmid) & $74.2 \pm 10.9^{\mathrm{b}}$ & $90 \pm 7.0$ \\
$\mathrm{E}=$ Transfectant control (without DNA plasmid : $0.75 \mu \mathrm{L}$ transfectant) & $76.2 \pm 7.6^{\mathrm{b}}$ & $95 \pm 3.0$ \\
$\mathrm{~F}=$ Negative control (negative control without DNA plasmid and transfectant) & $57.2 \pm 11.4^{\mathrm{ab}}$ & $75 \pm 1.0$ \\
\hline
\end{tabular}

Notes: The value in the same column followed by different superscript letters are statistically different $(P<0.05)$. The values are presented in average $\pm \mathrm{SD} ;{ }^{*}=$ analysis was performed for 50 embryos and 30 larvae that were merged (pooled samples)
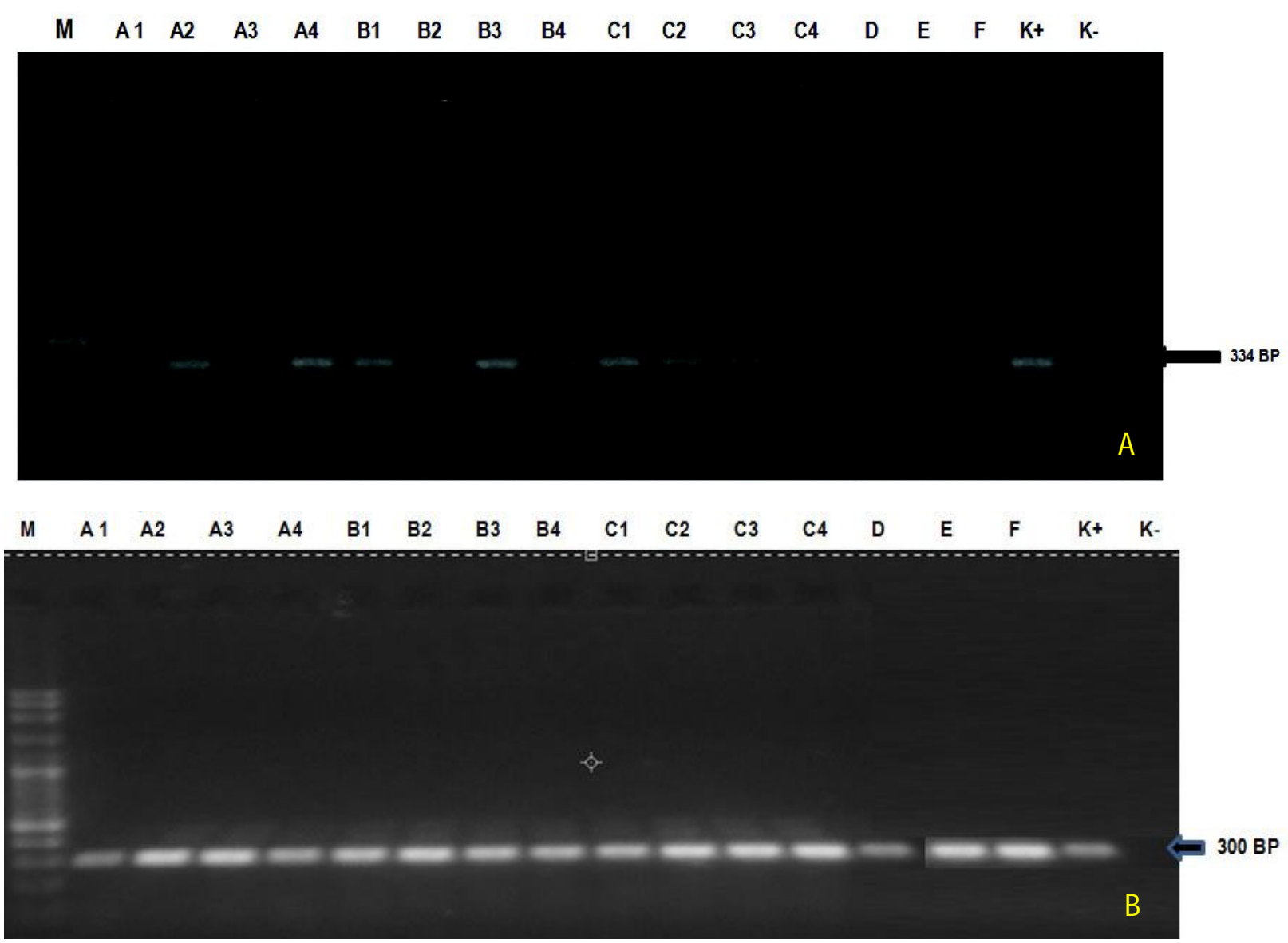

Figure 1. Analysis of exogenous gene encoding Siamese catfish growth hormone (PhGH) in B. imbellis embryos and larvae after transfection using different DNA concentrations; Figure $A$ is a product of PCR amplification using PhGH specific primers; Figure $B$ is using $\beta$-actin primer. Treatment $\mathrm{A}=$ DNA 0:25 $\mu \mathrm{L} ; \mathrm{B}=$ DNA 0:50 $\mu \mathrm{L} ; \mathrm{C}=$ DNA $0.75 \mu \mathrm{L} ; \mathrm{K}=$ water negative control as template. Numbers 1, 2, 3, 4 after A, B, and C are embryo sampling times, 18, 36, 54, and 72 hours after transfection respectively. $M=$ DNA fragment marker size 


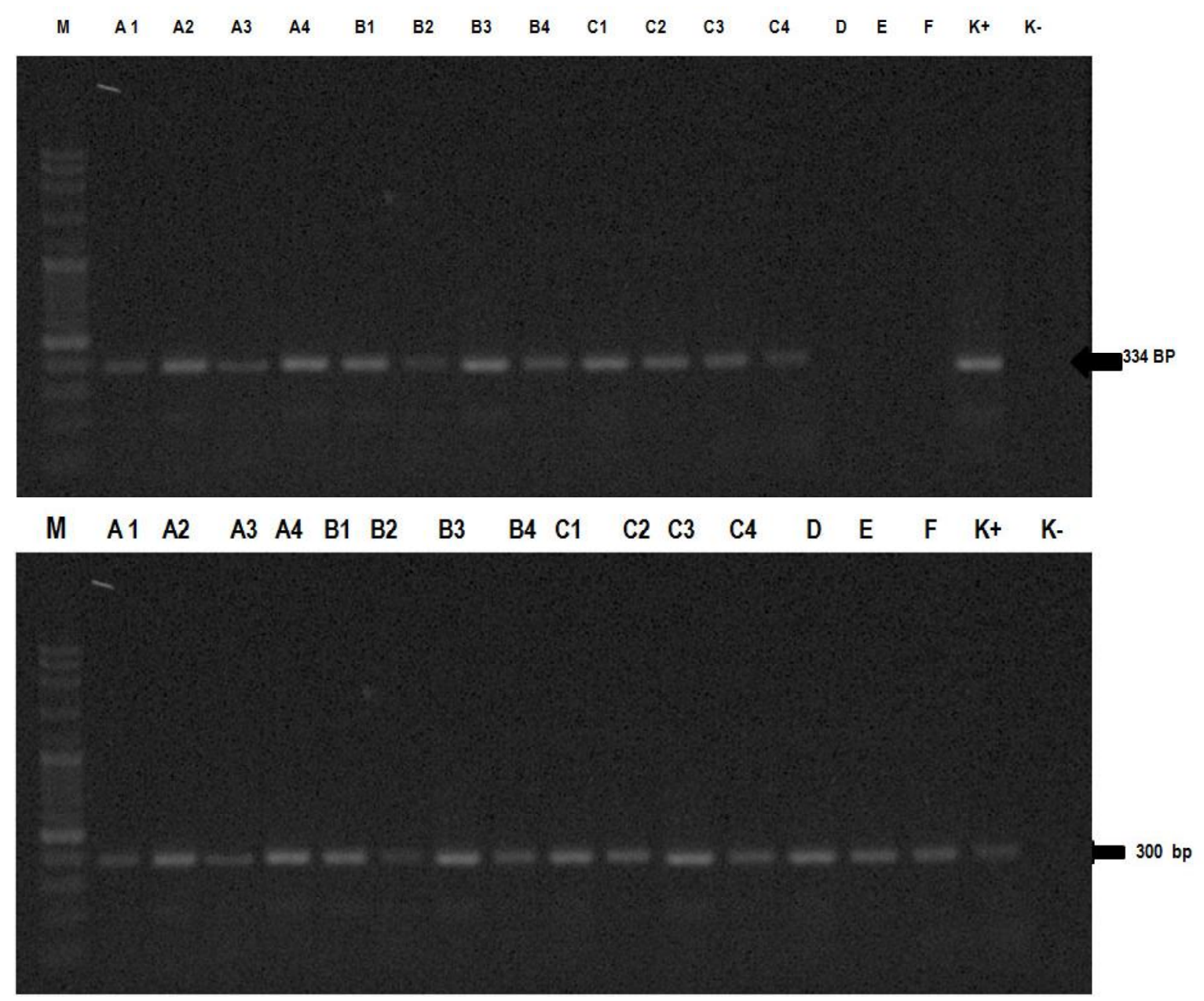

Figure 2. Expression analysis of Siamese catfish growth hormone (PhGH) mRNA on B. imbellis embryo and larvae after transfection using different DNA concentrations. Figure in above were PCR amplification product using PhGH specific primer. Figure below were using $\beta$-actin primer. Treatment $\mathrm{A}=0.25 \mu \mathrm{L} ; \mathrm{B}=0.50 \mu \mathrm{L} ; \mathrm{C}=0.75 \mu \mathrm{L} ; \mathrm{D}=\mathrm{DNA}$ control; $\mathrm{E}=$ transfectant control; $\mathrm{F}=$ without $\mathrm{DNA}$ without transfectant; $\mathrm{K}=$ water negative control for template; number 1, 2, 3, 4 after A, B, and C letters were embryos sampling time $18,36,54$, and 72 hours after transfection, respectively. $M=$ fragment DNA size marker

Hatching rate of transfection treatment $\mathrm{A}(0.75$ $\mu \mathrm{L}$ transfectant and $0.25 \mu \mathrm{L}$ DNA) was slightly higher $(P<0.05)$ than other transfection treatments, and hatching rate of treatment $A$ was the same $(P>0.05)$ with all controls (Table 1 ). It shows that ratios between transfectant and DNA in treatment A, and 30 minutes of transfection length did not interfere hatching and development of eggs. Decline of hatching rate in treatment $B$ and $C$ while the amount of DNA was higher than treatment $A$ were expected because the quality of the eggs that were used. Possibility for those eggs has not been fertilized due to randomized eggs retrieval from the foam nest. It is supported by the research reported by Parenrengi et al. (2011) where hatching rate of transfection tiger shrimp eggs were $38.1 \%$ in average. Study conducted by Sun et al. (2005) on transfection method in white shrimp showing a better method compared to microinjection and electrophoresis based on hatching rate results, but microinjection method on medaka fish Oryzias latifes provides a slightly high hatching rate $(70 \%$ compared to $78 \%$ hatching rate on control fish (Winkler et al. 1991), Clarias sp. catfish hatching rate was $55.0 \%$ to 93.3\%(Ath-thar, 2007), and red sea bream Pagrus major around 53\%63\% (Kato et al., 2007). At various methods of gene transfer that were treated to some aquaculture fishes showed that there were not any effect on eggs hatching rate. Likewise for the transfection method that was executed to $B$. imbellis that transfectant and DNA ratio did not unduly influence 
fish eggs hatching. In addition, $0.25 \mu \mathrm{L}$ DNA volume which is the best on this research is in line with that recommended in the manual of X-treme Gene.

Larval survival rate up to age four days was shown in Table 1. Survival rate of larvae in treatment A was the same control, but higher than treatment $B$ and $C$. Thus transfection in treatment $B$ and $C$ was still in affected, a minimum until larvae reach four days aged so the survival rate was low. Low survival rate occurs due to DNA and transfectant ratio which is not appropriate, where its effect on larval survival rate was also reported by Parenrengi et al. (2011) on tiger shrimp and Sun et al. (2005) on white shrimp. On both studies, shrimp transfection was using JetPEI transfectant. Although the transfectant used on this study were different with the previous study, but it's equally not affect hatching rate and larvae survival rate.

By using a transfection method, PhGH genes can be detected in embryos and larvae of betta fish (Figure 1). These results provide great opportunities to produce transgenic betta. Furthermore, mRNA $\mathrm{PhGH}$ expression can also be detected in embryos and larvae (Figure 2). This shows that carp $\beta$-actin promoter regulate expression of transgene in betta fish actively. PhGH gene expression is potentially spur betta fish growth, and this will require a further test of the next generation.

Success of making transgenic fish using transfection methods have been reported on zebrafish (Robles \& Cancela, 2007). Same result is thought can be produced on betta fish. Currently, there are 1,800 candidates of transgenic betta fish larvae $\mathrm{F}-0$. In subsequent research, it is also necessary to identify germline transmitter of transgenic fish to generate the first and the next generation of transgenic fish.

Embryos transfection research results can also be reported on shrimp that has been done by Parenrengi et al. (2010) and Yasawa et al. (2005) and it can be concluded based on eggs number and hatching rate that were used, transfection method has a great potential to be applied on gene transfer of betta fish. Studies using three methods of gene transfer namely microinjection, electroporation, and gene transfection on white shrimp conducted by Sun et al. (2005).

Based on observations of $B$. imbellis embryo, two cells phase begin four minutes after spawning, at $28^{\circ} \mathrm{C}-29^{\circ} \mathrm{C}$. In this study, transfection was done prior to two cells formation or before four minutes. This relatively same were also done in tiger shrimp, the transfection is performed five minutes shortly after spawning, before chorionic protector is formed, which would impede the process of transfection.
Length of transfection was 50 minutes after spawning (Parenrengi et al., 2011) and for white shrimp, embryos two cells formations begin to occur 55 minutes after spawning so the gene transfection should be performed prior to such time (Sun et al., 2005). Transfectant that was used on transgenic tiger and white shrimp productions was JetPEI (Parenrengi et al., 2010; Sun et al., 2005), and a lipids solution for zebrafish (Robles \& Cancela, 2007).

On genes transfers using a microinjection method, gene transfer is generally carried out in one cell phase. In this study, transfection was conducted about 1-4 minutes after spawning. Three hundreds until four hundreds eggs are produced by Betta's broodstock for one spawning time. Therefore, it takes a lot of broodstocks that spawn simultaneously to obtain eggs in considerable amounts. Transfection process in stages according to the availability of spawning broodstocks can also be performed.

\section{CONCLUSION}

The highest hatching and larvae survival rate were obtained using X-treme Gene $0.75 \mu \mathrm{L}$ and DNA plasmid $0.25 \mu \mathrm{L}$ (concentration $50 \mu \mathrm{g} / \mathrm{mL}$ ). Furthermore, $\beta$-actin promoter can regulate mRNA expression of $\mathrm{PhGH}$ gene in B. imbellis. Therefore, X-treme Gene transfectant and carp $\beta$-actin promoter can be used to create transgenic $B$. imbellis.

\section{ACKNOWLEDGEMENT}

The author would like to thank to the team of researchers and genetic's technicians of Research Institute and Development of Ornamental Fish Culture for the assistance during the study. The research was funded by DIPA budget in 2014.

\section{REFERENCES}

Alimuddin, Yoshizaki, G., Carman, 0., \& Sumantadinata, K. (2003). Aplications gene transfer in aquaculture. J. Akuakultur Indonesia, 2(1), 4150. (in Indonesian).

Ath-thar, M.H.F. (2007). The effectiveness of â-actin promoter medaka fish Oryzias latipes with marker genes hrGFP (Humanized renilla reniformis green fluorescent protein) in catfish (Clarias sp.) descendants F0 . Essay. Department of Aquaculture, Fisheries and Marine Science. Bogor Agricultural Institute. Bogor, 57 pp. (in Indonesian).

Beaumont, A.R., \& Hoare, K. (2003). Biotechnology and genetics in fisheries and aquaclture. Blackwell Science, Oxford. UK, $158 \mathrm{pp}$.

Boonanuntanasarn, S., Yoshizaki, G., Takeuchi, Y., Morita, T., \& Tekeuchi, T. (2002). Gene knockdown in rainbow trout embryos using antisense 
morpholino phosphorodiamidate oligonucleotides. Mar. Biotechnol., 4, 56-266.

Devlin, R.H., Sakhrani, D., Tymchuk, W.E., Rise, M.L., $\&$ Goh, B. (2004). Domestication and growth hormone transgenesis cause similar changes in gene expression in coho salmon (Oncorhynchus kisutch). Proc. Natl. Acad. Sci. USA, 106(9), 3047-3052.

Dewi, R.R.S.P.S. (2010). Studies over-expression of the growth hormone gene by elelctroporation sperm to create transgenic catfish siamese fast growing. Disertasi. Bogor Agricultural Institute. Bogor, 75 pp. (in Indonesian).

Dewi, R.R.S.P.S., Alimuddin, Sudrajat, A.0., \& Sumantadinata, K. (2012). The effectiveness of transfer of the transfer and expression of gene catfish siamese PhGH. J. Ris. Akuakultur, 7(2), 171180. (in Indonesian).

Dunham, R.A. (2004). Status genetically modified (transgenic) fish: research and application. Department of Fisheries and Allied Aquacultures, Auburn University, Alabama. USA, 23 pp.

Gaiano, N., Allende, M., Amsterdam, A., Kawakami, K., \& Hopkins, N. (1996). Highly efficient germline transmission of proviral insertions in zebrafish. Proc. Natl. Acad. Sci. USA, 93, 7777-7782.

Gusrina, Alimuddin, Sumantadinata, K, \& Widyastuti U. (2009). Transfer gen penyandi hormon pertumbuhan ikan nila (tiGH) pada ikan lele (Clarias sp.) dengan metode mikroinjeksi. J. Ris. Akuakultur, 4(3), 333-340.

IBC. (2013). International Betta congress. A Giant Betta Journal, $2 \mathrm{pp}$.

Kato, K., Takagi, M., Tamaru, Y., Akiyama, S., Konishi, T., Murata, O., \& Kumai, H. (2007). Construction of an expression vector containing a $\beta$-actin promoter region for gene transfer by microinjection in Red Sea Bream Pagrus major. Fish. Sci., 73, 440445.

Kavumpurath, S., Anderson, O., Kisen, G., \& Alestrom, P. (1993). Gene transfer methods and luciferase gene expression in zebrafish, Brachydanio rerio (Hamilton). Israeli J. Aquacult.-Bamidgeh, 45, 154163.

Khoo, H.W. (2000). Transgenesis and its applications in aquaculture. Asian Fish. Sci., 8, 1-25.

Kobayashi, S.I., Alimuddin, Morita, T., Miwa, M., Lu, J., Endo, M., Takeuci, T., \& Yoshikazi, G. (2007). Transgenic Nile tilapia (Oreochromis niloticus) overexpressing growth hormone show reduced ammonia excretion. Aquaculture, 270, 427-435.

Kusrini, E., Kusumah, R.V., Prasetio, A.B., Murniasih, S., Rahmawati, R., Cindelaras, S., \& Alimuddin. (2012). Verification individual F-0 wild brood fish betta (Betta sp.) the result of genetic engineering. Research report 2012, 15 pp. (in Indonesian).
Nam, Y.K., Noh, J.K., Cho, Y.S., Cho, H.J., Cho, K.N., Kim, G., \& Kim, D.S. (2001). Dramatically accelerated growth and extraordinary gigantism of transgenic mud loach Misgurnus mizolepis. Transgenic Res., 10, 353-362.

Parenrengi, A., Alimuddin, Sukenda, Sumantadinata, K., \& Tenriulo, A. (2010). Antiviral activity test promoter in black tiger shrimp Penaeus monodon using EGFP gene as a marker. Paper presented at the Aquaculture Technology Innovation Forum (FITA), Lampung, 18 pp. (in Indonesian).

Parenrengi, A, Tenriulo, A., Tonnek, S., \& Lante, S. (2011). Transfer of antiviral genes in the embryo black tiger shrimp, Penaeus monodon in sharing DNA concentration. J. Ris. Akuakultur, 6(3), 353361. (in Indonesian).

Prasetio, A.B., Kusrini, E., Kusumah, R.V., Cindelaras, S., \& Murniasih, S. (2012). Effectiveness of the transfection method of gene transfer in nature zygote betta (Betta imbellis). J. Ris. Akuakultur, 8(2), 191-199. (in Indonesian).

Robles, V., \& Cancela, M.L. (2007). Lipid-based transfection as a method for gene delivery in zebrafish (Danio rerio) embryos. Aquaculture Research, 38, 1317-1322.

Sheela, S.G., Chen, J.D., Mathavan, S., \& Pandian, T.J. (1998). Construction, electroporatic transfer and expression of ZpâypGH and ZpârtGHin zebrafish. J. Biosci., 23, 565-576.

Sun, P.S., Venzon, N.C., Calderon, F.R.O., \& Esaki, D.M. (2005). Evaluation of methods for DNA delivery into shrimp zygotes of Penaeus (Litopenaeus) vannamei. Aquaculture, 243, 19-26.

Tsai, H.J. (2000). Electroporated sperm mediation of a gene transfer system for finfish and shellfish. Molecular Reproduction and Development, 56, 281284.

Volckaert, F.A., Hellemans, B.A., Galbusera, P., Ollevier, F., Sekkali, B., \& Belayew A. (1994). Replication, expression, and fate of foreign DNA during embryonic and larval development of the African catfish (Clarias gariepinus). Mol. Mar. Biol. Biotechnol., 3, 57-69.

Winkler, C., Vielkind, J.R., \& Schartl, M. (1991). Transient expression of foreign DNA during embryonic and larval development of the medaka fish (Oryzias latipes). Mol. Gen. Genet., 226, 129-140.

Yasawa, R., Watanabe, K., Koyama, T., Ruangapan, T., Tassanakajon, A., Hirono, I., \& Aoki, T. (2005). Development of gene transfer technology for black tiger shrimp (Penaeus monodon). J. Exp. Z00., 303, 1104-1109.

Yoshizaki, G. (2001). Gene transfer in salmonidae: application to aquaculture. Suisanzoshoku, 49(2), 137-142. 